\title{
Could sugar intake initiate or aggravate non-alcoholic fatty liver during aging? An integrative review
}

\author{
TEODORO, A. C. S. ${ }^{1}$, NUCCI, R. A. B. ${ }^{1}$, GAMA, E. F. ${ }^{2}$, \\ RODRIGUES, G. M. ${ }^{3}$ and MACHADO-LIMA, A. ${ }^{4}$
}

\author{
${ }^{1}$ Laboratory of Morphoquantitative Studies and Immunohistochemistry, Aging Sciences, Universidade \\ São Judas Tadeu - USJT, Rua Taquari, 546, CEP 03166-000, Mooca, São Paulo, SP, Brazil \\ ${ }^{2}$ Laboratory of Morphoquantitative Studies and Immunohistochemistry, Department of Physical Education, \\ Universidade São Judas Tadeu - USJT, Rua Taquari, 546, CEP 03166-000, São Paulo, SP, Brazil \\ ${ }^{3}$ Department of Physical Education, Universidade São Judas Tadeu - USJT, \\ Rua Taquari, 546, CEP 03166-000, São Paulo, SP, Brazil \\ ${ }^{4}$ Post Graduation Course, Aging Sciences, Universidade São Judas Tadeu - USJT, \\ Rua Taquari, 546, CEP 03166-000, Mooca, São Paulo, SP, Brazil \\ *E-mail: annacaroll92souza@gmail.com
}

\begin{abstract}
Introduction: Non-alcoholic fatty liver disease (NAFLD) is part of the metabolic syndrome (MS) which is a clustering of risk factors that increase the incidence of cardiovascular events and diabetes mellitus (DM). The population aging process brings with it higher prevalence of MS. The prevalence of NAFLD has increased considerably, simultaneously with the expansion of MS, ranging from $15 \%$ to $25 \%$ in the general population. In Brazil, overweight plus obesity corresponds to $40 \%$ of the adult population and the prevalence found in the elderly age group reaches $81 \%$. Thus, the carbohydrate intake has been identified as a key factor for the development of NAFLD. Objective: The purpose of this integrative review is to assess whether the sugar consumption by adults and elders may influence in the development and progression of NAFLD in individuals with or without metabolic syndrome. Materials and methods: The integrative review search was performed on PubMed database during September 2015. The selection criteria was adults and elderly people; sugar intake, such as, glucose or fructose; liver fat or NAFLD. Our major outcome was the hepatic profile because it is related to the sugar intake. We excluded review papers and studies with animals, as well as papers that were not related to our selection criteria. Results: The studies analyzed the sugar intake on hepatic de novo lipogenesis or NAFLD. Conclusion: We conclude in the most of the articles sugar intake and NAFLD have a positive correlation. However further studies are needed to elucidate the mechanism that sugars intake, mainly fructose, leads to NAFLD, or aggravating it.
\end{abstract}

Keywords: non-alcoholic fatty liver disease, NAFLD, sugar intake, fructose, aging.

\section{Introduction}

The non-alcoholic fatty liver disease (NAFLD) is characterized histologically by intracellular accumulation of triglycerides (TG) in more than $5 \%$ of hepatocytes (SCHINDHELM, DIAMANT, DEKKER et al., 2006) from hepatic parenchymal (SHETH, GORDON and CHOPRA, 1997; ÂNGULO, 2002; SASS, CHANG and CHOPRA, 2005), and understand, clinically, from hepatic steatosis to nonalcoholic steatohepatitis (NASH) which can lead to cirrhosis and even to hepatocellular carcinoma (ADAMS, SANDERSON, LINDOR et al., 2005; BUGIANESI, LEONE, VANNI et al., 2002). The pathological picture refers to liver damage induced by alcohol, but occurs in people who do not have significant alcohol consumption. NAFLD may be considered the leading cause of morbidity and mortality related to liver diseases due to their potential to progress to liver failure (CARVALHEIRA and SAAD, 2006).

NAFLD is characterized by changes in liver tissue ranging from fat accumulation in the liver to $\mathrm{NASH}$, cirrhosis and hepatocellular carcinoma. Thus, the metabolic syndrome aids in risk of development of hepatocarcinoma by NAFLD and NASH (CARVALHEIRA and SAAD, 2006).

Inadequate weight gain associated with visceral fat accumulation predetermines the development of insulin resistance (IR), dyslipidemia, hypertension and pro-inflammatory state and pro-thrombotic which are risk factors for developing type 2 diabetes and cardiovascular disease (CVD) (GRUNDY, CLEEMAN, DANIELS et al., 2005; EZQUERRA, VÁZQUEZ and BARRERO, 2008), besides being components in the metabolic syndrome (MS).

In 2006 the World Health Organization (WHO) estimates that the elderly population will triple between 2000 and 2050 , from 600 million to 2 billion elderly (WORLD..., 2008). According to the latest projection of the population conducted by IBGE (Instituto Brasileiro de Geografia e Estatística), the proportion for the group of seniors with 60 years or older has the sharp increase, from $13.8 \%$ in 2020 to $33.7 \%$ in 2060 . The group of seniors with 60 years and older will be 
greater than the group of children up to 14 years after 2030 (INSTITUTO..., 2013a).

According to the WHO report, released in 2014, of the 56 million deaths that occurred in 2012, 38 million were caused by chronic non communicable diseases (NCDs), among the most prominent are cardiovascular disease (CVD), cancer, chronic respiratory diseases and diabetes (WORLD..., 2014). The metabolic syndrome (MS) is a clustering of risk factors that increase the incidence of cardiovascular events and diabetes mellitus (DM). The population aging process brings with it higher prevalence of MS (SAAD, CARDOSO, DE ANDRADE MARTINS et al. (2014) and represents a high risk for cardiovascular disease, DM, mobility changes (BLAZER, HYBELS and FILLENBAUM, 2006), cognitive impairment (DIK, JONKER, COMIJS et al., 2007) and depression in the elderly (KOPONEN, JOKELAINEN, KEINANENKIUKAANNIEMI et al., 2008). And for individuals in this age group, the consequences of MS are even more pronounced, mainly due to physiological changes associated with aging (STRAGMALIA, GRECO, GUGLIELMI et al., 2010).

The prevalence of NAFLD has increased considerably, simultaneously with the expansion of MS, ranging from $15 \%$ to $25 \%$ in the general population (HAUKELAND, KONOPSKI, LINNESTAD et al., 2005; MARCHESINI, BUGIANESI, FORLANI et al., 2003). In the US adult population is estimated that the prevalence of overweight plus the obesity is greater than 64\% (FLEGAL, CARROLL, OGDEN et al., 2010). In Brazil, data provided from IBGE showed that overweight plus obesity account for $40 \%$ of the adult population (INSTITUTO..., 2013b). The prevalence found in the elderly age group reaches $81 \%$ (NATIONAL..., 2001 ), since during the aging process, the organism gradually loses its efficiency (LEITE and FERNADES, 2011).

The etiology of NAFLD may be justified, in part, by increased influx of lipids, due to higher lipolysis, predominantly in the adipose tissue along with excess of fat from the diet (ZIVKOVIC, GERMAN and SANYAL, 2007). Furthermore, increased hepatic lipogenesis, and reduction in mitochondrial beta-oxidation or very low lipoprotein (VLDL) secretion, may also predispose to accumulation of lipids in the liver (RECTOR, THYFAULT, WEI et al., 2008; FABBRINI, MOHAMMED, MAGKO et al., 2008; BROWNING and HORTON, 2004; OTA, GAYET and GINSBERG, 2008; POSTIC and GIRARD, 2008). Hepatic lipids accumulation, results in injury to hepatocytes, which can cause inflammation leading to fibrosis (DUVNJAK, LEROTIĆ, BARSIĆ et al., 2007; TARGHER, BERTOLINI, RODELLA et al., 2008; WEI, RECTOR, THYFAULT et al., 2008).

Individual action of metabolic and nutritional factors in the pathogenesis of NAFLD it is not yet fully elucidated. Insulin resistance appears to have a key role in the development of hepatic steatosis and some authors consider it as a causal factor for the development of the disease (MUSSO, GAMBINO, DE MICHIELI et al., 2003; CAVE, DEACIUC, MENDEZ et al., 2007). Some studies have been conducting in patients with NAFLD in order to identify whether food consumption patterns may be associated with predisposition of the disease, and some studies suggest the association of a high-fat diet with increased consumption of carbohydrates (RECTOR, THYFAULT, WEI et al., 2008; THUY, LADURNER, VOLYNETS et al., 2008; SILBERNAGEL, MACHANN, UNMUTH et al., 2011; ABDELMALEK, LAZO, HORSKA et al., 2012; KANERVA,
SANDBOGE, KAARTINEN et al., 2014; SCHWARZ, NOWOROLSKI, WEN et al., 2015).

Carbohydrate intake has been identified as a key factor for the development of NAFLD (THUY, LADURNER, VOLYNETS et al., 2008). Results of a study in humans suggested that a high carbohydrate diet could be the main cause of NAFLD, increasing the chance of achieving later stages disease (SOLGA, ALKHURAISHE, CLARK et al., 2004; TOSHIMITSU, MATSUURA, OHKUBO et al., 2007). Within this context, fructose, a monosaccharide, is appointed for causing NAFLD (ABDELMALEK, SUZUKI, GUY et al., 2010). This reducing sugar is found in processed products such as snack foods, breakfast cereals and crackers. Its excess may be associated with stimulation of triglyceride synthesis in the liver (VOS, COLVIN, BELT et al., 2012).

Due to the instability of the molecular furanose ring, fructose promotes frutosylation of protein and formation of reactive oxygen species, requiring extra supply of antioxidants, since patients with NAFLD have lower blood levels of these substances (LIM, MIETUS-SNYDER, VALENTE et al., 2010). Studies showed that exacerbated consumption of fructose increases fat mass, de novo lipogenesis (DNL), inflammation and induces insulin resistance and postprandial hypertriglyceridemia, particularly in overweight individuals (GLUSHAKOVA, KOSUGI, RONCAL et al., 2008; LIGHT, TSANZI, GIGLIOTTI et al., 2009; CIRILLO, GERSCH, MU et al., 2009; CALAFELL, BOADA, SANTIDRIAN et al., 2009; STANHOPE, SCHWARZ, KEIM et al., 2009; FAEH, MINEHIRA, SCHWARZ et al., 2005).

Furthermore, diets containing large amounts of fructose are associated with increased TG (BANTLE, RAATZ, THOMAS et al., 2000; TEFF, ELLIOTT, TSCHÖP et al., 2004; CHONG, FIELDING and FRAYN, 2007; STANHOPE and HAVEL, 2009; LÊ, ITH, KREIS et al., 2009; HUDGINS, PARKER, LEVINE et al., 2011), apolipoprotein B100 (ApoB 100), and low lipoprotein (LDL) levels (STANHOPE and HAVEL, 2009), resulting in an atherogenic profile that is associated with increased risk of cardiovascular disease (CVD) (KANNEL and VASAN, 2009), and diabetes mellitus (BASU, YOFFE, HILLS et al., 2013; ROMAGUERA, NORAT, WARK et al., 2013). Some studies showed that long-term intake of fructose is able to increase the deposit of visceral fat and hepatic steatosis (STANHOPE, SCHWARZ, KEIM et al., 2009; MAERSK, BELZA, STØDKILDE-JØRGENSEN et al., 2011; ZIVKOVIC, GERMAN and SANYAL, 2007).

The purpose of this integrative review is to assess whether the sugar consumption, commonly present in the Western diet, by adults and elders may influence in the development and progression of NAFLD in individuals with or without metabolic syndrome.

\section{Materials and Methods}

The integrative review search was performed on PubMed database during September 2015 using the following Mesh terms, entry terms, and related keywords: (Fatty Liver OR Hepatic Steatosis OR Liver Steatosis OR Steatosis of Liver) AND (Sugar Consumption OR Carbohydrates Consumption OR Sugars Consumption OR Carbohydrate Consumption) AND (Elderly OR Aged OR Aging). The words on our search were used to research on Cochrane Library to verify if the aims of this study were analyzed by other papers on the last ten 
years. We selected the papers published in the last 10 years. We included studies published in English, Portuguese and Spanish. The selection criteria was adults and elderly people; sugar intake, such as, glucose or fructose; liver fat or fatty liver or NAFLD. Our major outcome was the hepatic profile because it is related to the sugar intake. Consequently, sugar intake is associated to fatty liver and NAFLD. We excluded review papers and studies with animals, as well as papers that were not related to our selection criteria, such as, teenager subjects only, probiotic studies and multiple pathologies that could interfere in the hepatic profile.

\section{Results and Discussion}

We can see at Figure 1 the fluxogram of the article selection process and exclusion criteria. Our search yielded nine papers included in this review (PARKS, SKOKAN, TIMLIN et al., 2008; THUY, LADURNER, VOLYNETS et al., 2008; ABDELMALEK, SUZUKI, GUY et al., 2010; HUDGINS, PARKER, LEVINE et al., 2011; SILBERNAGEL, MACHANN,
UNMUTH et al., 2011; STANHOPE, GRIFFEN, BREMER et al., 2011 ; ABDELMALEK, LAZO, HORSKA et al., 2012; KANERVA, SANDBOGE, KAARTINEN et al., 2014; SCHWARZ, NOWOROLSKI, WEN et al., 2015) as seen at Table 1 .

The hepatic de novo lipogenesis that is associated with the increase liver fat and consequently NAFLD was analyzed in five studies (PARKS, SKOKAN, TIMLIN et al., 2008; THUY, LADURNER, VOLYNETS et al., 2008; SILBERNAGEL, MACHANN, UNMUTH et al., 2011; STANHOPE, GRIFFEN, BREMER et al., 2011; SCHWARZ, NOWOROLSKI, WEN et al., 2015) and the association between sugar intake and NAFLD was analyzed in four studies (THUY, LADURNER, VOLYNETS et al., 2008; ABDELMALEK, SUZUKI, GUY et al., 2010; ABDELMALEK, LAZO, HORSKA et al., 2012; KANERVA, SANDBOGE, KAARTINEN et al., 2014).

The studies analyzed the sugar intake of fructose alone (ABDELMALEK, SUZUKI, GUY et al., 2010; ABDELMALEK, LAZO, HORSKA et al., 2012; KANERVA, SANDBOGE,

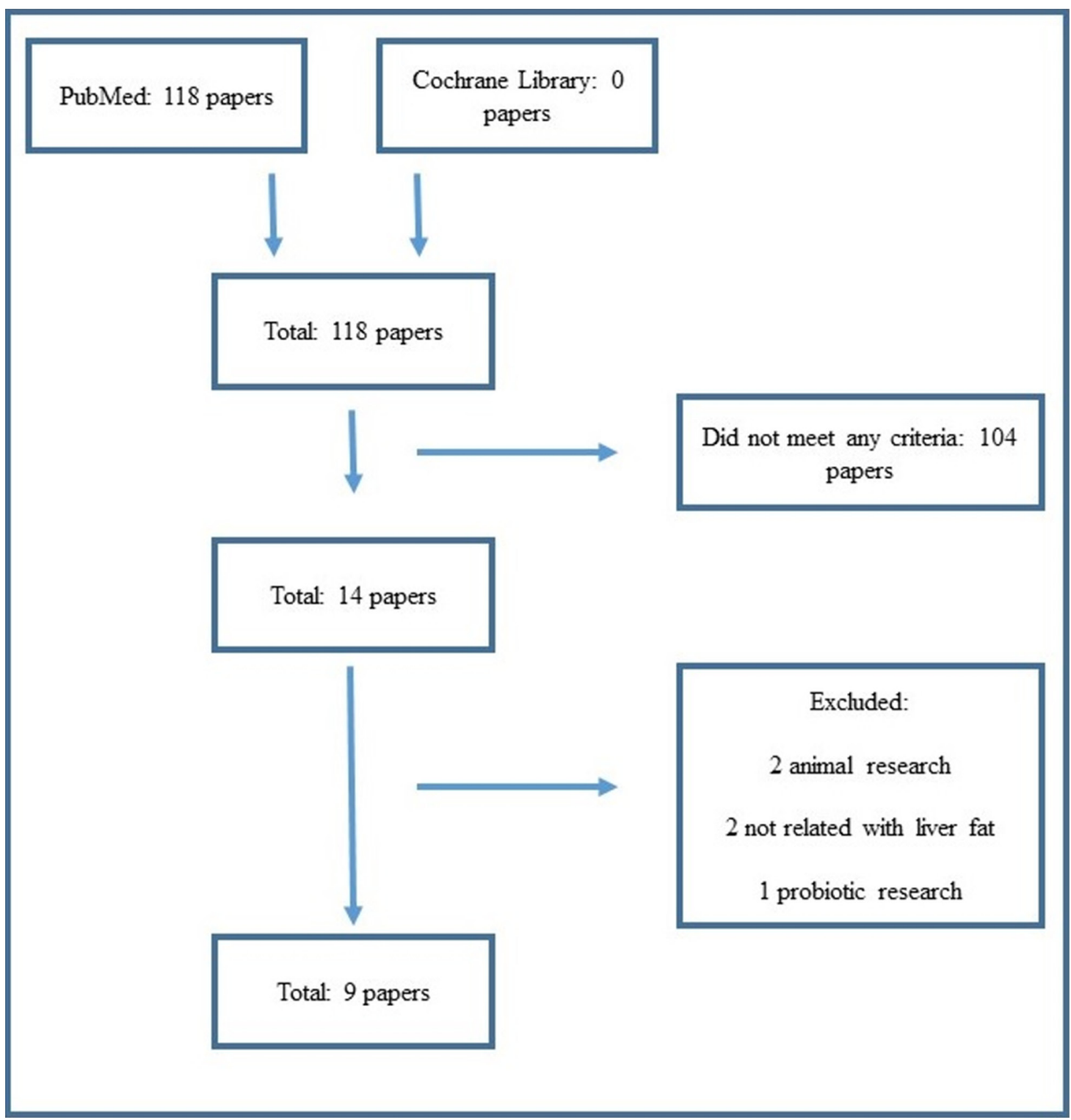

Figure 1. Fluxogram of the article selection process and exclusion criteria. 
TEODORO, A. C. S., NUCCI, R. A. B., GAMA, E. F.

Table 1. Data description of all studies included in the integrative review.

\begin{tabular}{|c|c|c|c|c|c|c|}
\hline Study & Age (range) & Participants & Pathology & Sugar & Intake & $\begin{array}{c}\text { Duration } \\
\text { of the } \\
\text { study }\end{array}$ \\
\hline \multirow{2}{*}{$\begin{array}{l}\text { Parks, Skokan, } \\
\text { Timlin et al. (2008) }\end{array}$} & $28 \pm 8(\mathrm{NR})$ & 15 & None & $\begin{array}{l}\text { Fructose and } \\
\text { glucose }\end{array}$ & $\begin{array}{l}15.9 \pm 5.4 \% \text { after the } \\
50: 50 \text { treatment }\end{array}$ & $\begin{array}{c}\text { Not } \\
\text { mentioned }\end{array}$ \\
\hline & & & & & $\begin{array}{l}16.9 \pm 5.2 \% \text { after the } \\
25: 75 \text { treatment } \\
\text { (glucose:fructose) }\end{array}$ & \\
\hline \multirow{4}{*}{$\begin{array}{l}\text { Thuy, Ladurner, } \\
\text { Volynets et al. (2008) }\end{array}$} & $\begin{array}{l}\text { Control Group: } \\
47 \pm 7 \text { (NR) }\end{array}$ & 6 & NAFLD & $\begin{array}{l}\text { Fructose, } \\
\text { glucose and } \\
\text { sucrose }\end{array}$ & $\begin{array}{l}\text { Control Group: } \\
37.0 \pm 4.0 \text { glucose; } \\
48 \pm 7.2 \text { sucrose; } \\
41.0 \pm 3.2\end{array}$ & $\begin{array}{l}\text { Not } \\
\text { mentioned }\end{array}$ \\
\hline & $\begin{array}{l}\text { NAFLD Group: } \\
55 \pm 4() \mathrm{NR}\end{array}$ & 12 & Steatosis & & $\begin{array}{l}\text { NAFLD Group: } \\
48.2 \pm 4.3 \text { glucose; } \\
57.3 \pm 6.3 \text { sucrose; } \\
51.5 \pm 5.2 \text { fructose }\end{array}$ & \\
\hline & & & Steatohepatitis & & & \\
\hline & & & $\begin{array}{l}\text { Steatohepatitis } \\
\text { with fibrosis }\end{array}$ & & & \\
\hline \multirow{3}{*}{$\begin{array}{l}\text { Abdelmalek, Suzuki, } \\
\text { Guy et al. (2010) }\end{array}$} & $\begin{array}{c}\text { Group 0 } \\
\text { servings: } \\
53.9 \pm 1.2(\mathrm{NR})\end{array}$ & 427 & NAFLD & Fructose & $\begin{array}{c}\text { Analyzed by dietary } \\
\text { questionnaire }\end{array}$ & 3 months \\
\hline & $\begin{array}{l}\text { Group > } 0 \text { and } \\
<7 \text { servings: } \\
47.5 \pm 0.8(\mathrm{NR})\end{array}$ & & $\begin{array}{l}\text { Lobular } \\
\text { inflammation }\end{array}$ & & & \\
\hline & $\begin{array}{c}\text { Group } \geq 7 \\
\text { servings: } \\
41.4 \pm 1.0(\mathrm{NR})\end{array}$ & & $\begin{array}{l}\text { Fibrosis stage } \\
\mathrm{la}, \mathrm{lb} \text { and } \mathrm{lc}\end{array}$ & & & \\
\hline \multirow{2}{*}{$\begin{array}{l}\text { Hudgins, Parker, } \\
\text { Levine et al. (2011) }\end{array}$} & $\begin{array}{l}\text { Protocol 1: } \\
\text { NR (18-75) }\end{array}$ & 15 & None & $\begin{array}{l}\text { Fructose and } \\
\text { glucose }\end{array}$ & $\begin{array}{c}\text { Protocol } 1: 1.4 \mathrm{~g} / \mathrm{kg} \\
\text { every } 6 \text { hours }\end{array}$ & 3 months \\
\hline & $\begin{array}{l}\text { Protocol 2: } \\
\text { NR }(28-65)\end{array}$ & 15 & & & $\begin{array}{l}\text { Protocol } 2: \mathrm{lg} / \mathrm{kg} \\
\text { fructose plus } 1 \mathrm{~g} / \mathrm{kg} \\
\text { glucose per day }\end{array}$ & \\
\hline \multirow{2}{*}{$\begin{array}{l}\text { Silbernagel, Machann, } \\
\text { Unmuth et al. (2011) }\end{array}$} & $30.5 \pm 2.0(\mathrm{NR})$ & 10 & None & $\begin{array}{l}\text { Fructose and } \\
\text { glucose }\end{array}$ & $\begin{array}{l}150 \mathrm{~g} \text { of fructose per } \\
\text { day }\end{array}$ & 4 weeks \\
\hline & & 10 & & & $\begin{array}{c}150 \mathrm{~g} \text { of glucose per } \\
\text { day }\end{array}$ & \\
\hline \multirow{2}{*}{$\begin{array}{l}\text { Stanhope, Griffen, } \\
\text { Bremer et al. (2011) }\end{array}$} & NR (40-70) & 15 & None & $\begin{array}{l}\text { Fructose and } \\
\text { glucose }\end{array}$ & $\begin{array}{l}25 \% \text { of daily energy } \\
\text { intake in fructose }\end{array}$ & 10 weeks \\
\hline & & 15 & & & $\begin{array}{l}25 \% \text { of daily energy } \\
\text { intake in glucose }\end{array}$ & \\
\hline $\begin{array}{l}\text { Abdelmalek, Lazo, } \\
\text { Horska et al. (2012) }\end{array}$ & NR (45-76) & 244 & None & Fructose & $\begin{array}{c}\text { Analyzed by } \\
\text { food frequency } \\
\text { questionnaire (FFQ) }\end{array}$ & 6 months \\
\hline \multirow{4}{*}{$\begin{array}{l}\text { Kanerva, Sandboge, } \\
\text { Kaartinen et al. (2014) }\end{array}$} & $\begin{array}{c}\text { Group 1: } \\
61.6 \pm 0.2(\mathrm{NR})\end{array}$ & 403 & NAFLD & Fructose & $\begin{array}{c}\text { Group 1: } \\
10.6 \pm 1.3^{3} \mathrm{~g} / \mathrm{kg}\end{array}$ & 3 years \\
\hline & $\begin{array}{c}\text { Group 2: } \\
61.7 \pm 0.2(\mathrm{NR}) \\
\end{array}$ & 403 & & & $\begin{array}{c}\text { Group 2: } \\
18.6 \pm 1.0 \mathrm{~g} / \mathrm{kg}\end{array}$ & \\
\hline & $\begin{array}{c}\text { Group 3: } \\
61.5 \pm 0.2(\mathrm{NR}) \\
\end{array}$ & 402 & & & $\begin{array}{c}\text { Group 3: } \\
25.2 \pm 1.0 \mathrm{~g} / \mathrm{kg}\end{array}$ & \\
\hline & $\begin{array}{c}\text { Group 4: } \\
61.6 \pm 0.2(\mathrm{NR})\end{array}$ & 403 & & & $\begin{array}{c}\text { Group 4: } \\
38.1 \pm 1.0 \mathrm{~g} / \mathrm{kg}\end{array}$ & \\
\hline \multirow{2}{*}{$\begin{array}{l}\text { Schwarz, Noworolski, } \\
\text { Wen et al. (2015) }\end{array}$} & NR (18-65) & Group 1: 4 & None & Fructose & $\begin{array}{l}25 \% \text { of daily energy } \\
\text { intake in fructose }\end{array}$ & 18 days \\
\hline & & Group 2: 4 & & & $\begin{array}{l}\text { Isocaloric diet with } \\
\text { fructose }\end{array}$ & \\
\hline
\end{tabular}

$\mathrm{NR}=$ not reported 
KAARTINEN et al., 2014; SCHWARZ, NOWOROLSKI, WEN et al., 2015), fructose or glucose (PARKS, SKOKAN, TIMLIN et al., 2008; HUDGINS, PARKER, LEVINE et al., 2011; SILBERNAGEL, MACHANN, UNMUTH et al., 2011; STANHOPE, GRIFFEN, BREMER et al., 2011) and fructose, glucose or sucrose (THUY, LADURNER, VOLYNETS et al., 2008).

The assessment of the outcomes were variable in most of the papers. Three articles that utilized food frequency questionnaire to measured sugar consumption (ABDELMALEK, SUZUKI, GUY et al., 2010; ABDELMALEK, LAZO, HORSKA et al., 2012; KANERVA, SANDBOGE, KAARTINEN et al., 2014) analyzed lipids profile in the liver and metabolic changes with different methodologies. Some of them were glucose tolerance test (ABDELMALEK, SUZUKI, GUY et al., 2010), hepatic ATP depletion (ABDELMALEK, LAZO, HORSKA et al., 2012), liver histology (ABDELMALEK, SUZUKI, GUY et al., 2010), fasting lipid profile (ABDELMALEK, SUZUKI, GUY et al., 2010), fatty Liver Index (FLI) and NAFLD liver fat score (KANERVA, SANDBOGE, KAARTINEN et al., 2014).

Others six studies with oral sugar doses, in both short and long-term, utilized distinct techniques to determine hepatic metabolic disturbances, such as magnetic resonance spectroscopy (SILBERNAGEL, MACHANN, UNMUTH et al., 2011; SCHWARZ, NOWOROLSKI, WEN et al., 2015), glucose tolerance test (SILBERNAGEL, MACHANN, UNMUTH et al., 2011), percentage of palmitate (HUDGINS, PARKER, LEVINE et al., 2011), hepatic expressions of plasminogen activator inhibitor 1 (PAI-1) (THUY, LADURNER, VOLYNETS et al., 2008) and lipogenesis analyzed by infusion of ${ }^{13} \mathrm{Cl}$-acetate (PARKS, SKOKAN, TIMLIN et al., 2008).

One metabolic process that is related to NAFLD is the conversion of fructose to fat (hepatic de novo lipogenesis [DNL)] (SCHWARZ, NOWOROLSKI, WEN et al., 2015). Compared with glucose, which is primarily metabolized in extrahepatic tissues, fructose is primarily metabolized in the liver, where it bypasses key initial regulatory steps in the glycolytic pathway, thus providing an unregulated source of acetyl coenzyme A for DNL (SAMUEL, 2011).

Parks, Skokan, Timlin et al. (2008) aimed to determine the magnitude by which acute consumption of fructose in a morning bolus would stimulate lipogenesis immediately and after a subsequent meal in six healthy subjects in a random blinded design, followed by a standardized lunch $4 \mathrm{~h}$ later. The method consisted in subjects complete a control test of $100 \%$ glucose and a mixture of 50:50 (glucose:fructose) and one of 25:75 (glucose:fructose). They concluded that acute intake of fructose stimulates lipogenesis and may create a metabolic milieu that enhances subsequent esterification of fatty acids flowing to the liver to elevate TG synthesis, subsequently, increasing liver fat (PARKS, SKOKAN, TIMLIN et al., 2008). These data corroborate with Schwarz, Noworolski, Wen et al. (2015) that studied eight healthy men for consecutive nine days comparing the effects of a high-fructose weight-maintaining diet to those of an isocaloric diet with the same macronutrient distribution but in which complex carbohydrate was substituted for fructose. They measured liver fat by magnetic resonance spectroscopy, and concluded that the short-term high-fructose intake was associated with increased DNL and liver fat (SCHWARZ, NOWOROLSKI, WEN et al., 2015).

However, Silbernagel, Machann, Unmuth et al. (2011) concluded that the effects of very high fructose and very high glucose in hyperenergetic diets on glucose metabolism and body fat composition (such as liver fat, visceral fat, subcutaneous abdominal fat and intramyocellular lipids of the tibialis anterior muscle) were not different in the healthy participants.

Hudgins, Parker, Levine et al. (2011) studying three different sugar beverages, as well as oral bolus of fructose and glucose in palmitate in a randomized crossover design, concluded that a single oral bolus of fructose and glucose rapidly increased serum TG and TG palmitate, concluding that excessive chronic hepatic synthesis of palmitate contributes to the development of fatty liver and other metabolic consequences. In order to complement these data, consumption of sugar-sweetened beverages has been shown to be associated with insulin resistance (YOSHIDA, MCKEOWN, ROGERS et al., 2007), fatty liver (ASSY, NASSER, KAMAYSE et al., 2008; OUYANG, CIRILLO, SAUTIN et al., 2008), type 2 diabetes (SCHULZE, MANSON, LUDWIG et al., 2004; MONTONEN, JARVINEN, KNEKT et al., 2007; PALMER, BOGGS, KRISHNAN et al., 2008), and other diseases. Data provided from Stanhope, Griffen, Bremer et al. (2011) demonstrated that the specific effects of fructose, but not of glucose and insulin excursions, contribute to the adverse effects of consuming sugar-sweetened beverages on lipids and insulin sensitivity leading to an increased lipogenesis that may contribute to metabolic consequences (STANHOPE, GRIFFEN, BREMER et al., 2011).

The increased lipogenesis consequently increase fat in the liver causing NAFLD (PARKS, SKOKAN, TIMLIN et al., 2008; HUDGINS, PARKER, LEVINE et al., 2011; SILBERNAGEL, MACHANN, UNMUTH et al., 2011; STANHOPE, GRIFFEN, BREMER et al., 2011; NATIONAL..., 2014; SCHWARZ, NOWOROLSKI, WEN et al., 2015). When the fat accompanies inflammation and liver cell damage, the condition is called nonalcoholic steatohepatitis, or NASH (NATIONAL..., 2014). The inflammation and damage can cause fibrosis, which eventually can lead to cirrhosis (NATIONAL..., 2014). Some studies provided information about subjects with NAFLD and dietary fructose intake (THUY, LADURNER, VOLYNETS et al., 2008; ABDELMALEK, SUZUKI, GUY et al., 2010; ABDELMALEK, LAZO, HORSKA et al., 2012; KANERVA, SANDBOGE, KAARTINEN et al., 2014).

Kanerva, Sandboge, Kaartinen et al. (2014) studied the cross-sectional association between fructose intake and NAFLD by using the Fatty Liver Index (FLI) and the NAFLD liver fat score, as well as, triglycerides, $\gamma$-glutamil-transferase, waist circumference, weight and height to calculate BMI, and a validated 131 -item food frequency questionnaire to evaluate the habitual fructose and other dietary intake. The results did not support that high intake of fructose is associated with a higher prevalence of NAFLD as assessed by using the FLI and NAFLD liver fat score (KANERVA, SANDBOGE, KAARTINEN et al., 2014). However, the study showed risk of bias once it was concerned to older adults Finns, suggesting that more studies are need to corroborate with these data (KANERVA, SANDBOGE, KAARTINEN et al., 2014). Nevertheless, Abdelmalek, Suzuki, Guy et al. (2010) reported that fructose consumption was associated with decreased age, male gender, hypertriglyceridemia, low HDLcholesterol, decreased serum glucose, increased calorie intake and hyperuricemia (ABDELMALEK, SUZUKI, GUY et al., 2010). On the other hand, another study from Abdelmalek, Lazo, Horska et al. (2012), concluded that high fructose consumption depletes hepatic ATP and impairs recovery from 
ATP depletion following an intravenous fructose challenge. The subjects with high uric acid demonstrate a greater nadir in hepatic ATP in response to fructose (ABDELMALEK, LAZO, HORSKA et al., 2012). Both high dietary fructose and elevated uric acid level may predict more severe hepatic ATP depletion in response to fructose and hence may be risk factors for the development and progression of NAFLD (ABDELMALEK, LAZO, HORSKA et al., 2012).

In addition, Thuy, Ladurner, Volynets et al. (2008), studied NAFLD and the association between increased plasma endotoxin and plasminogen activator inhibitor 1 (PAI-1) with fructose intake, demonstrated that not only, was the plasma PAI-1 concentration positively correlated with the plasma endotoxin concentration and hepatic TLR mRNA expression, but also hepatic mRNA expression of PAI-I was positively associated with dietary intakes of fructose. Concluding that dietary fructose intake, increased intestinal translocation of bacterial endotoxin, and PAI-1 may contribute to the development of NAFLD (THUY, LADURNER, VOLYNETS et al., 2008).

Chung, Ma, Patel et al. (2014) in a systematic review with meta-analysis, elucidated that the apparent association between indexes of liver health (i.e. liver fat, DNL, NAFLD) and sugar intake (i.e. fructose) appear to be confounded by excessive energy intake.

\section{Conclusion}

We conclude in the most of the articles sugar intake and NAFLD have a positive correlation. However further studies are needed to elucidate how sugars intake, mainly fructose, can start the process of liver fat accumulation leading to NAFLD, or aggravating it. Most of the papers included in this review had different methodologies to assess this relation, however we suggest more studies that could associated better this methodologies to elucidate the effects of sugar intake on the liver fat and consequently to NAFLD .

\section{References}

ABDELMALEK, MF., SUZUKI, A., GUY, C., UNALP-ARIDA, A., COLVIN, R., JOHNSON, RJ. and ANNA MAE DIEHL FOR THE NONALCOHOLIC STEATOHEPATITIS CLINICAL RESEARCH NETWORK. Increased fructose consumption is associated with fibrosis severity in patients with nonalcoholic fatty liver disease. Hepatology (Baltimore, Md.), 2010, vol. 51, n. 6, p. 1961-1971.

ABDELMALEK, MF., LAZO, M., HORSKA, A., BONEKAMP, S., LIPKIN, EW., BALASUBRAMANYAM, A., BANTLE, JP., JOHNSON, RJ., DIEHL, AM., CLARK, JM. and THE FATTY LIVER SUBGROUP OF THE LOOK AHEAD RESEARCH GROUP. Higher dietary fructose is associated with impaired hepatic adenosine triphosphate homeostasis in obese individuals with type 2 diabetes. Hepatology (Baltimore, Md.), 2012, vol. 56, n. 3, p. 952-960.

ADAMS, LA., SANDERSON, S., LINDOR, KD. and ANGULO, P. The histological course of nonalcoholic fatty liver disease: a longitudinal study of 103 patients with sequential liver biopsies. Journal of Hepatology, 2005, vol. 42, n. 1, p. 132-138.

ANGUlO, P. Nonalcoholic fatty liver disease. The New England Journal of Medicine, 2002, vol. 346, p. 1221-1231.

ASSY, N., NASSER, G., KAMAYSE, I., NSEIR, W., BENIASHVILI, Z., DJIBRE, A. and GROSOVSKI, M. Soft drink consumption linked with fatty liver in the absence of traditional risk factors. Canadian Journal of Gastroenterology, 2008, vol. 22, p. 811-816.
BANTLE, JP., RAATZ, SK., THOMAS, W. and GEORGOPOULOS, A. Effects of dietary fructose on plasma lipids in healthy subjects. The American Journal of Clinical Nutrition, 2000, vol. 5, n. 72, p. 1128-1134.

BASU, S., YOFFE, P., HILLS, N. and LUSTIG, RH. The relationship of sugar to population-level diabetes prevalence: an econometric analysis of repeated cross-sectional data. PLoS One, 2013, vol. 8, n. 2 , p. e57873.

BLAZER, DG., HYBELS, CF. and FILLENBAUM, GG. Metabolic syndrome predicts mobility decline in a community-based sample of older adults. Journal of the American Geriatrics Society, 2006, vol. 3 , n. 54, p. 502-506.

BROWNING, JD. and HORTON, JD. Molecular mediators of hepatic steatosis and liver injury. The Journal of Clinical Investigation, 2004, vol. 114, n. 2 , p. 147.

BUGIANESI, E., LEONE, N., VANNI, E., MARCHESINI, G., BRUNELLO, F., CARUCCI, P., MUSSO, A., DE PAOLIS, P., CAPUSSOTTI, L., SALIZZONI, M. and RIZZETTO, M. Expanding the natural history of nonalcoholic steatohepatitis: from cryptogenic cirrhosis to hepatocellular carcinoma. Gastroenterology, 2002, vol. 123, n. 1, p. 134-140.

CALAFELL, R., BOADA, J., SANTIDRIAN, AF., GIL, J., ROIG, T., PERALES, JC. and BERMUDEZ, J. Fructose 1,6-bisphosphate reduced TNF-alpha-induced apoptosis in galactosamine sensitized rat hepatocytes through activation of nitric oxide and cGMP production. European Journal of Pharmacology, 2009, no. 610, p. 128-133.

CARVALHEIRA, JBC. and SAAD, MJA. Doenças associadas à resistência à insulina/hiperinsulinemia, não incluídas na síndrome metabólica. Arquivos Brasileiros de Endocrinologia e Metabologia, 2006, vol. 50, n. 2, p. 360-367.

CAVE, M., DEACIUC, I., MENDEZ, C., SONG, Z., JOSHIBARVE, S., BARVE, S. and MCCLAIN, C. Nonalcoholic fatty liver disease: predisposing factors and the role of nutrition. The Journal of Nutritional Biochemistry, 2007, vol. 18, n. 3, p. 184-195.

CHONG, MF., FIELDING, BA., and FRAYN, KN. Mechanisms for the acute effect of fructose on postprandial lipemia. The American Journal of Clinical Nutrition, 2007, vol. 85, n. 6, p. 1511-1520.

CHUNG, M., MA, J., PATEL, K., BERGER, S., LAU, J. and LICHTENSTEIN, AH. Fructose, high-fructose corn syrup, sucrose, and nonalcoholic fatty liver disease or indexes of liver health: a systematic review and meta-analysis. The American Journal of Clinical Nutrition, 2014, vol. 100, n. 3, p. 833-849.

CIRILLO, P., GERSCH, MS., MU, W., SCHERER, PM., KIM, KM., GESUALDO, L., HENDERSON, GN., JOHNSON, RJ. and SAUTIN, YY. Ketohexokinase-dependent metabolism of fructose induces proinflammatory mediators in proximal tubular cells. Journal of the American Society of Nephrology, 2009, vol. 20, p. 545-553.

DIK, MG., JONKER, C., COMIJS, HC., DEEG, DJ., KOK A., YAFFE K. and PENNINX, BW. Contribution of metabolic syndrome components to cognition in older individuals. Diabetes Care, 2007, vol. 30, n. 10, p. 2655-2660.

DUVNJAK, M., LEROTIĆ, I., BARSIĆ, N., TOMASIĆ, V., VIROVIĆ JUKIĆ, L. and VELAGIĆ, V. Pathogenesis and management issues for non-alcoholic fatty liver disease. World Journal of Gastroenterology, 2007, vol. 13, n. 34, p. 4539-4550.

EZQUERRA, EA., VÁZQUEZ, JMC. and BARRERO, AA. Obesity, metabolic Syndrome, and diabetes: cardiovascular implications and therapy. Revista Española de Cardiología (English Ed.), 2008, vol. 61, n. 7 , p. $752-764$

FABBRINI, E., MOHAMMED, BS., MAGKO, SF., KORENBLAT, KM., PATTERSON, BW. and KLEIN, S. Alterations in adipose tissue and hepatic lipid kinetics in obese men and women with nonalcoholic fatty liver disease. Gastroenterology, 2008, vol. 134, n. 2, p. 424-431. 
FAEH, D., MINEHIRA, K., SCHWARZ, JM., PERIASAMY, R., PARK, S. and TAPPY, L. Effect of fructose overfeeding and fish oil administration on hepatic de novo lipogenesis and insulin sensitivity in healthy men. Diabetes, 2005, vol. 54, p. 1907-1913.

FLEGAL, KM., CARROLL, MD., OGDEN, CL. and CURTIN, LR. Prevalence and trends in obesity among US adults, 1999-2008. Journal of the American Medical Association, 2010, vol. 3, p. 235-241.

GLUSHAKOVA, O., KOSUGI, T., RONCAL, C., MU, W., HEINIG, M., CIRILLO, P., SÁNCHEZ-LOZADA, LG., JOHNSON, RJ., and NAKAGAWA, T. Fructose induces the inflammatory molecule ICAM1 in endothelial cells. Journal of the American Society of Nephrology, 2008, vol. 19, p. 1712-1720.

GRUNDY, SM., CLEEMAN, JI., DANIELS, SR., DONATO, KA., ECKEL, RH., FRANKLIN, BA., GORDON, DJ., KRAUSS, RM., SAVAGE, PJ., SMITH JUNIOR, SC., SPERTUS, JA. and COSTA, F. Diagnosis and management of the metabolic syndrome an American Heart Association/National Heart, Lung, and Blood Institute scientific statement. Crit Pathw Cardiol., 2005, vol. 112, n. 17, p. 2735-2752.

HAUKELAND, JW., KONOPSKI, Z., LINNESTAD, P., AZIMY, S., MARIT LØBERG, E., HAALAND, T., BIRKELAND, K. and BJØRO, $\mathrm{K}$. Abnormal glucose tolerance is a predictor of steatohepatitis and fibrosis in patients with non-alcoholic fatty liver disease. Scandinavian Journal of Gastroenterology, 2005, vol. 40, n. 12, p. 1469-1477.

HUDGINS, LC., PARKER, TS., LEVINE, DM. and HELLERSTEIN, MK. A dual sugar challenge test for lipogenic sensitivity to dietary fructose. The Journal of Clinical Endocrinology and Metabolism, 2011, vol. 96 , n. 3, p. 861-868.

INSTITUTO BRASILEIRO DE GEOGRAFIA E ESTATÍSTICA - IBGE. Diretoria de Pesquisas, Coordenação de Índices de preços, Pesquisa de Orçamentos familiares, 2012-2013. Rio de Janeiro: IBGE, 2013a. Available from: <http://www.ibge.gov.br/home/estatistica/ populacao/condicaodevida/pof/2013/pof2013.pdf>. Access in: 10 Sept. 2015.

INSTITUTO BRASILEIRO DE GEOGRAFIA E ESTATÍSTICA - IBGE. Indicadores sociodemográficos e de Saúde no Brasil. Rio de Janeiro, IBGE, 2013b.</bok>

KANERVA, N., SANDBOGE, S., KAARTINEN, EN., MÄNNISTÖ, S. and ERIKSSON, JG. Higher fructose intake is inversely associated with risk of nonalcoholic fatty liver disease in older Finnish adults. The American Journal of Clinical Nutrition, 2014, vol. 100, n. 4, p. 1133-1138.

KANNEL, WB. and VASAN, RS. Triglycerides as vascular risk factors: new epidemiologic insights. Current Opinion in Cardiology, 2009, vol. 24, n. 4 , p. 345-350.

KOPONEN, H., JOKELAINEN, J., KEINANEN-KIUKAANNIEMI, S., KUMPUSALO, E. and VANHALA, M. Metabolic syndrome predisposes to depressive symptoms: a population-based 7-year follow-up study. The Journal of Clinical Psychiatry, 2008, vol. 69, n. 2 , p. $178-182$.

LÊ, KA., ITH, M., KREIS, R., FAEH, D., BORTOLOTTI, M., TRAN, C., BOESCH, C. and TAPPY, L. Fructose overconsumption causes dyslipidemia and ectopic lipid deposition in healthy subjects with and without a family history of type 2 diabetes. The American Journal of Clinical Nutrition, 2009, vol. 89, n. 6, p. 1760-1765.

LEITE, C. and FERNANDES, MG. Sindrome metabólica em idosos: explorando tendências atuais. São Paulo: Vetor Editora, 2011. Available from: <http://portaldoenvelhecimento.org.br/noticias/artigos/ sindrome-metabolica-em-idososexplorando-tendencias-atuais.html.>. Access in: 25 Sept. 2015

LIGHT, HR., TSANZI, E., GIGLIOTTI, J., MORGAN, K. and TOU, JC. The type of caloric sweetener added to water influences weight gain, fat mass, and reproduction in growing Sprague-Dawley female rats. Experimental Biology and Medicine (Maywood, N.J.), 2009 , vol. 234, p. 651-661.

LIM, JS., MIETUS-SNYDER, M., VALENTE, A., SCHWARZ, JM. and LUSTIG, RH. The role of fructose in the pathogenesis of NAFLD and the metabolic syndrome. Nature Reviews. Gastroenterology o Hepatology, 2010, vol. 7, p. 251-264.

MAERSK, M., BELZA, A., STØDKILDE-JØRGENSEN, H., RINGGAARD, S., CHABANOVA, E., THOMSEN, H., PEDERSEN, SB., ASTRUP, A. and RICHELSEN, B. Sucrose-sweetened beverages increase fat storage in the liver, muscle, and visceral fat depot: a 6-mo randomized intervention study. The American Journal of Clinical Nutrition, 2011, vol. 95, n. 2, p. 283-289.

MARCHESINI, G., BUGIANESI, E., FORLANI, G., CERRELLI, F., LENZI, M., MANINI, R., NATALE, S., VANNI, E., VILLANOVA, N., MELCHIONDA, N. and RIZZETTO, M. Nonalcoholic fatty liver, steatohepatitis, and the metabolic syndrome. Hepatology (Baltimore, Md.), 2003, vol. 37, n. 4, p. 917-923.</jrn> ****

MONTONEN, J., JARVINEN, R., KNEKT, P., HELIOVAARA, $M$. and REUNANEN, A. Consumption of sweetened beverages and intakes of fructose and glucose predict type 2 diabetes occurrence. The Journal of Nutrition, 2007, vol. 137, p. 1447-1454.

MUSSO, G., GAMBINO, R., DE MICHIELI, F., CASSADER, M., RIZZETTO, M., DURAZZO, M., FAGÀ E., SILLI, B. and PAGANO, G. Dietary habits and their relations to insulin resistance and postprandial lipemia in nonalcoholic steatohepatitis. Hepatology (Baltimore, Md.), 2003, vol. 37, n. 4, p. 909-916.

NATIONAL CHOLESTEROL EDUCATION PROGRAM NCEP-ATP. Executive summary of the Third Report of the National Cholesterol Education Program (NCEP). Expert Panel on Detection, Evaluation and Treatment of High Cholesterol in Adults (ATP III). Journal of the American Medical Association, 2001, vol. 285, n. 025215, p. 2486-2497.

NATIONAL INSTITUTE OF DIABETES AND DIGESTIVE AND KIDNEY DISEASE CIRRHOSIS - NIDDK. Cirrhosis. USA: National Institue of Health, 2014. Available from: <http://www.niddk.nih. gov/health-information/health-topics/liver-disease/cirrhosis/Pages/ facts.aspx>. Access in: 27 Nov. 2015.

OTA, T., GAYET, C. and GINSBERG, HN. Inhibition of apolipoprotein $\mathrm{B} 100$ secretion by lipid-induced hepatic endoplasmic reticulum stress in rodents. The Journal of Clinical Investigation, 2008, vol. 118, n. 1, p. 316.

OUYANG, X., CIRILLO, P., SAUTIN, Y., MCCALL, S., BRUCHETTE, JL., DIEHL, AM., JOHNSON, RJ. and ABDELMALEK, MF. Fructose consumption as a risk factor for non-alcoholic fatty liver disease. Journal of Hepatology, 2008, vol. 48, p. 993-999.

PALMER, JR., BOGGS, DA., KRISHNAN, S., HU, FB., SINGER, M. and ROSENBERG, L. Sugar-sweetened beverages and incidence of type 2 diabetes mellitus in African American women. Archives of Internal Medicine, 2008, vol. 168, p. 1487-1492.

PARKS, EJ., SKOKAN, LE., TIMLIN, MT. and DINGFELDER, CS. Dietary sugars stimulate fatty acid synthesis in adults. The Journal of Nutrition, 2008, vol. 138, n. 6, p. 1039-1046.

POSTIC, C. and GIRARD, J. Contribution of de novo fatty acid synthesis to hepatic steatosis and insulin resistance: lessons from genetically engineered mice. The Journal of Clinical Investigation, 2008, vol. 118, n. 3, p. 829.

RECTOR, RS., THYFAULT, JP., WEI, Y. and IBDAH, JA. Nonalcoholic fatty liver disease and the metabolic syndrome: an update. World Journal of Gastroenterology, 2008, vol. 14, n. 2, p. 185.

ROMAGUERA, D., NORAT, T., WARK, PA., VERGNAUD, AC., SCHULZE, MB., VAN WOUDENBERGH, GJ., DROGAN, D., AMIANO, P., MOLINA-MONTES, E., SÁNCHEZ, MJ., BALKAU, B., BARRICARTE, A., BEULENS, JW., CLAVEL-CHAPELON, F., 
CRISPIM, SP., FAGHERAZZI, G., FRANKS, PW., GROTE, VA., HUYBRECHTS, I., KAAKS, R., KEY, TJ., KHAW, KT., NILSSON, P., OVERVAD, K., PALLI, D., PANICO, S., QUIRÓS, JR., ROLANDSSON, O., SACERDOTE, C., SIERI, S., SLIMANI, N., SPIJKERMAN, AM., TJONNELAND, A., TORMO, MJ., TUMINO, R., VAN DEN BERG, SW., WERMELING, PR., ZAMARA-ROS, R., FESKENS, EJ., LANGENBERG, C., SHARP, SJ., FOROUHI, NG., RIBOLI, E. and WAREHAM, NJ. Consumption of sweet beverages and type 2 diabetes incidence in European adults: results from EPIC-InterAct. Diabetologia, 2013, vol. 56, n. 7, p. 1520-1530.

SAAD, MAN., CARDOSO, GP., DE ANDRADE MARTINS, W., COCA, LG. and VELARDE, RADCF. Prevalência de síndrome metabólica em idosos e concordância entre quatro critérios diagnósticos. Arquivos Brasileiros de Cardiologia, 2014, vol. 102, n. 3, p. 263-269.

SAMUEL, VT. Fructose induced lipogenesis: from sugar to fat to insulin resistance. Trends in Endocrinology and Metabolism, 2011, vol. 22 , n. 2 , p. 60-65.

SASS, DA., CHANG, P. and CHOPRA, KB. Nonalcoholic fatty liver disease: a clinical review. Digestive Diseases and Sciences, 2005, vol. 50, p. 171-180.

SCHINDHELM, RK., DIAMANT, M., DEKKER, JM., TUSHUIZEN, ME., TEERLINK T. and HEINE R.J. Alanine aminotransferase as a marker of non-alcoholic fatty liver disease in relation to type 2 diabetes mellitus and cardiovascular disease. Diabetes/Metabolism Research and Reviews, 2006, vol. 22, n. 6, p. 437-443.

SCHULZE, MB., MANSON, JE., LUDWIG, DS., COLDITZ, GA., STAMPFER, MJ., WILLETT, WC. and HU, FB. Sugar-sweetened beverages, weight gain, and incidence of type 2 diabetes in young and middle-aged women. Journal of the American Medical Association, 2004, vol. 292, p. $927-934$.

SCHWARZ, J., NOWOROLSKI, SM., WEN, MJ., DYACHENKO, A., PRIOR, JL., WEINBERG, ME., HERRAIZ, LA., TAI, VW., BERGERON, N., BERSOT, TP., RAO, MN., SCHAMBELAN, M. and MULLIGAN, K. Effect of a high-fructose weight-maintaining diet on lipogenesis and liver fat. The Journal of Clinical Endocrinology and Metabolism, 2015, vol. 100, p. 2434-2442.

SHETH, SG., GORDON, FD. and CHOPRA, S. Nonalcoholic steatohepatitis. Annals of Internal Medicine, 1997, vol. 126, p. 137-145.

SILBERNAGEL, G., MACHANN, J., UNMUTH, S., SCHICK, F., STEFAN, N., HÄRING, HU. and FRITSCHE, A. Effects of 4-week very-high-fructose/glucose diets on insulin sensitivity, visceral fat and intrahepatic lipids: an exploratory trial. British Journal of Nutrition, 2011 , vol. 106, n. 1, p. 79-86.

SOLGA, S., ALKHURAISHE, AR., CLARK, JM., TORBENSON, M., GREENWALD, A., DIEHL, AM. and MAGNUSON, T. Dietary composition and nonalcoholic fatty liver disease. Digestive Diseases and Sciences, 2004, vol. 49, p. 1578-1583.

STANHOPE, KL., SCHWARZ, JM., KEIM, NL., GRIFFEN, SC., BREMER, AA., GRAHAM, JL., HATCHER, B., COX, CL., DYACHENKO, A., ZHANG, W., MCGAHAN, JP., SEIBERT, A., KRAUSS, RM., CHIU, S., SCHAEFER, EJ., AI, M., OTOKOZAWA, S., NAKAJIMA, K., NAKANO, T., BEYSEN, C., HELLERSTEIN, MK., BERGLUND, L. and HAVEL, PJ. Consuming fructose-sweetened, not glucose-sweetened, beverages increases visceral adiposity and lipids and decreases insulin sensitivity in overweight/obese humans. The Journal of Clinical Investigation, 2009, vol. 119, n. 5, p. 1322-1334.

STANHOPE, KL. and HAVEL, PJ. Fructose consumption: considerations for future research on its effects on adipose distribution, lipid metabolism, and insulin sensitivity in humans. The Journal of Nutrition, 2009, vol. 139, n. 6, p. 1236S-1241S.

STANHOPE, KL., GRIFFEN, SC., BREMER, AA., VINK, RG., SCHAEFER, EJ., NAKAJIMA, K., SCHWARZ, J., BEYSEN, C.,
BERGLUND, L., KEIM, NL. and HAVEL, PJ. Metabolic responses to prolonged consumption of glucose-and fructose-sweetened beverages are not associated with postprandial or 24-h glucose and insulin excursions. The American Journal of Clinical Nutrition, 2011, vol. 94, n. 1, p. 112-119.

STRAGMALIA, DA., GRECO, A., GUGLIELMI, G., DE MATTHAEIS, A. and VENDEMIALI, GL. Echocardiography and Dual Energy X-Ray Absorptiometry in the Elderly Patientes with Metabolic Syndrome: a comparasion of two different techniques to evaluate visceral fat distribution. The Journal of Nutrition, 2010, vol. 14, n. 1, p. 6-10.

TARGHER, G., BERTOLINI, L., RODELLA, S., ZOPPINI, G., LIPPI, G., DAY, C. and MUGGEO, M. Non-alcoholic fatty liver disease is independently associated with an increased prevalence of chronic kidney disease and proliferative/laser-treated retinopathy in type 2 diabetic patients. Diabetologia, 2008, vol. 51, n. 3, p. 444-450.

TEFF, KL., ELLIOTT, SS., TSCHÖP, M., KIEFFER, TJ., RADER, D., HEIMAN, M., TOWNSEND, RR., KEIM, NL., D'ALESSIO, D. and HAVEL, PJ. Dietary fructose reduces circulating insulin and leptin, attenuates postprandial suppression of ghrelin, and increases triglycerides in women. The Journal of Clinical Endocrinology and Metabolism, 2004, vol. 89, n. 6, p. 2963-2972.

THUY, S., LADURNER, R., VOLYNETS, V., WAGNER, S., STRAHL, S., KÖNIGSRAINER, A., MAIER, K., BISCHOFF, SC. and BERGHEIM, I. Nonalcoholic fatty liver disease in humans is associated with increased plasma endotoxin and plasminogen activator inhibitor 1 concentrations and with fructose intake. The Journal of Nutrition, 2008, vol. 138, n. 8, p. 1452-1455.

TOSHIMITSU, K., MATSUURA, B., OHKUBO, I., NIIYA, T., FURUKAWA, S., HIASA, Y., KAWAMURA, M., EBIHARA, K. and ONJI, M. Dietary habits and nutrient intake in non-alcoholic steatohepatitis. Nutrition (Burbank, Los Angeles County, Calif.), 2007, vol. 23, p. 46-52.

VOS, MB., COLVIN, R., BELT, P., MOLLESTON, JP., MURRAY, KF., ROSENTHAL, P., SCHWIMMER, JB., TONASCIA, J., UNALP, A., LAVINE, JE. and NASH CRN RESEARCH GROUP. Correlation of Vitamin E, uric acid, and diet composition with histologic features of pediatric NAFLD. Journal of Pediatric Gastroenterology and Nutrition, 2012, vol. 54, p. 90-96.

WEI, Y., RECTOR, RS., THYFAULT, JP. and IBDAH, JA. Nonalcoholic fatty liver disease and mitochondrial dysfunction. World Journal of Gastroenterology, 2008, vol. 14, n. 2, p. 193.

WORLD HEALTH ORGANIZATION - WHO. World health statistics. Geneva: WHO, 2008. Available from: <http://www.who. int/whosis/whostat/EN_WHS08_Full.pdf>. Access in: 01 Nov. 2015.

WORLD HEALTH ORGANIZATION - WHO. Global status report on noncommunicable diseases. Geneva: WHO, 2014. Available from: <http://www.who.int/nmh/publications/en/>. Access in: 02 Nov. 2015.

YOSHIDA, M., MCKEOWN, NM., ROGERS, G., MEIGS, JB., SALTZMAN, E., D'AGOSTINO, R. and JACQUES, PF. Surrogate markers of insulin resistance are associated with consumption of sugarsweetened drinks and fruit juice in middle and older-aged adults. The Journal of Nutrition, 2007, vol. 137, p. 2121-2127.

ZIVKOVIC, AM., GERMAN, JB. and SANYAL, AJ. Comparative review of diets for the metabolic syndrome: implications for nonalcoholic fatty liver disease. The American Journal of Clinical Nutrition, 2007, vol. 86, n. 2 , p. 285-300.

Received February 10, 2015 Accepted February 23, 2016 